\title{
KLINIK UTAMA REHABILITASI MEDIK DI BANJARMASIN
}

\author{
Dhia Ulfairuz Sukma \\ Program Studi Arsitektur Fakultas Teknik Universitas Lambung Mangkurat \\ dhiaufs15@gmail.com \\ Anna Oktaviana \\ Program Studi Arsitektur Fakultas Teknik Universitas Lambung Mangkurat \\ oktaviana@ulm.ac.id
}

\begin{abstract}
ABSTRAK
Seiring perkembangan ilmu kedokteran dan kebutuhan masyarakat, Kementerian Kesehatan (Kemenkes) mengeluarkan program di tahun 2017, yakni JKN atau Jaminan Kesehatan Nasional salah satunya tentang meningkatkan kuantitas dan kualitas pelayanan kesehatan.. Berdasarkan program tersebut Kementerian Kesehatan mengharapkan adanya persebaran fasilitas kesehatan di setiap daerah. Di Banjarmasin fasilitas kesehatan rehabilitatif masih kurang memenuhi secara kualitatif dan kuantitatifnya, salah satu fasilitas kesehatan rehabilitasi yaitu fasilitas rehabilitasi medik. Pasien rehabilitasi medik di rumah sakit di Kota Banjarmasin terus meningkat, sehingga pelayanan di rumah sakit menjadi kurang maksimal, karena itu diperlukan tambahan pelayanan rawat jalan melalui klinik. Keadaan di lapangan jumlah klinik rehabilitasi medik masih belum tersebar merata di Kota Banjarmasin dan secara kualitas klinik pada Kota Banjarmasin belum memenuhi persyaratan kebutuhan lingkungan fisik dimana lingkungan fisik merupakan faktor terbesar yang mempengaruhi proses penyembuhan. Pendekatan healing environment digunakan sebagai metode dan konsep penyelesaian masalah. Metode yang dilakukan yaitu dengan menentukan dan menganalisis fakta dari pelayanan rehabilitasi medik kemudian menerapkan aspek healing environment ke ruang. Aspek healing environment ini terdiri dari aspek alam, indera, dan psikologi.
\end{abstract}

Kata kunci : Klinik utama, rehabilitasi medik, healing environment.

\begin{abstract}
Along with the development of medical science and society needs Kementerian Kesehatan (Kemenkes) released a program in 2017, called JKN or Jaminan Kesehatan Nasional about improvement and build of quality of health infrastructure. Based on that program Kementrian Kesehatan expects the distribution of health facilities in each region. In Banjarmasin rehabilative health facilities is still not enough qualitatively and quantitatively, one of the rehabilitation health facilities is a medical rehabilitation facilities. Medical rehabilitation's patients in Banjarmasin hospitals always increase, so that hospital services become less than optimal, therefore additional outpatient services are needed through the clinic In reality amount of medical rehabilitation clinics are still not spread in Banjarmasin and the quality of clinics in Banjarmasin has not fulfill the requirements of physical environment where the physical environment is the biggest factor that affecting the healing process. The healing environment approach is used as a method and concept of problem solving. The method used is to determine and analyze the facts from the medical rehabilitation service, then applying the healing environment aspect to the space, both internal and external space. Healing environment aspect is consist of nature, senses, and psychology.

Keywords: Main clinic, medical rehabilitation, healing environment.
\end{abstract}

\section{PENDAHULUAN}

Seiring

kedokteran dan kebutuhan masyarakat, Kementerian

\begin{abstract}
Kesehatan
\end{abstract}
mengeluarkan program di tahun 2017, yaitu Jaminan Kesehatan Nasional (JKN), memenuhi sumber daya manusia bidang kesehatan, pembangunan dan 
pengembangan kualitas fasilitas dan infrastruktur kesehatan, dan meningkatkan kuantitas dan kualitas pelayanan kesehatan. Berdasarkan program tersebut Kementrian Kesehatan mengharapkan adanya persebaran fasilitas kesehatan di setiap daerah.

Dalam Upaya Kesehatan Perorangan (UKP) terdapat dua jenis upaya yang dapat dilakukan seseorang individu untuk untuk mencapai kriteria sehat,yaitu :

- Upaya kesehatan kuratif (pengobatan yaitu proses penyembuhan seseorang dari kondisi sakit.

- Rehabilitatif (pemulihan), tahapan merawat diri agar individu yang baru sembuh menjadi keadaan bugar kembali.

Di Banjarmasin fasilitas kesehatan kuratif sudah cukup tersebar di berbagai wilayah. Namun untuk fasilitas kesehatan rehabilitatif dapat dikatakan kurang memenuhi secara kualitatif dan kuantitatifnya. Salah satu fasilitas kesehatan rehabilitatif adalah pelayanan rehabilitasi medik, persebaran fasilitas rehabilitasi medik di Banjarmasin dijabarkan pada tabel berikut:

Tabel 1 Rumah sakit dengan fasilitas rehabilitasi medik

\begin{tabular}{|c|c|c|}
\hline No & Nama Rumah Sakit & Alamat \\
\hline 1 & $\begin{array}{l}\text { RS Umum Daerah } \\
\text { Ulin }\end{array}$ & $\begin{array}{l}\text { Jl. Achmad Yani } \\
\text { Banjarmasin }\end{array}$ \\
\hline 2 & RS Sari Mulia & $\begin{array}{l}\text { Jl. Pangeran Antasari } \\
\text { Nomor } 139\end{array}$ \\
\hline 3 & RS Islam & $\begin{array}{l}\text { Jl. S. Parman, Gang } \\
\text { Purnama Nomor } 88\end{array}$ \\
\hline 4 & RS Suaka Insan & $\begin{array}{l}\text { Jl. Zafri } \quad \text { Zam-Zam } \\
\text { Nomor } 60\end{array}$ \\
\hline 5 & RS Bhayangkara & Jl. A. Yani Km. 4 \\
\hline 6 & RS Anshari Shaleh & $\begin{array}{ll}\text { Jl.Brigjend } & \text { H.Hasan } \\
\text { Basri No.1 } & \\
\end{array}$ \\
\hline
\end{tabular}

Sumber: Data Pribadi

Tabel 2 Klinik dengan fasilitas rehabilitasi medik

\begin{tabular}{|l|l|l|}
\hline No & \multicolumn{1}{|c|}{ Nama Klinik } & \multicolumn{1}{c|}{ Alamat } \\
\hline 1 & $\begin{array}{l}\text { Klinik } \\
\text { Banjar Terapi Fisioterapi }\end{array}$ & $\begin{array}{l}\text { Jl. Mahligai, Sungai } \\
\text { Lulut, Kec. Banjarmasin } \\
\text { Timur }\end{array}$ \\
\hline
\end{tabular}

\begin{tabular}{|l|l|l|}
\hline 2 & $\begin{array}{l}\text { Klinik Fisioterapi } \\
\text { Madhira Husada }\end{array}$ & $\begin{array}{l}\text { Jl. Tembus Hikmah } \\
\text { Banua, Kec. } \\
\text { Banjarmasin Timur }\end{array}$ \\
\hline 3 & $\begin{array}{l}\text { Klinik Fisioterapi dan } \\
\text { Apotik Barito Farma }\end{array}$ & $\begin{array}{l}\text { Jl. Kinibalu, Tlk. Dalam, } \\
\text { Banjarmasin Tengah }\end{array}$ \\
\hline 4 & $\begin{array}{l}\text { Klinik Muhammadiyah } \\
\text { Klinik }\end{array}$ & $\begin{array}{l}\text { Jl. Letjen S. Parman, } \\
\text { Banjarmasin Barat }\end{array}$ \\
\hline 5 & Fuparno & $\begin{array}{l}\text { Jl. Simp. Perdagangan } \\
\text { II, Pangeran, } \\
\text { Banjarmasin Utara }\end{array}$ \\
\hline
\end{tabular}

Sumber: Data Pribadi

Berdasarkan tabel di atas jumlah fasilitas pelayanan rehabilitasi medik di Banjarmasin tersebar pada tujuh rumah sakit dan lima klinik. Jumlah pasien pada beberapa pelayanan rehabilitasi medik tersebut mengalami kenaikan dua tahun terakhir.

Ditinjau secara kualitas ruang klinik rehabilitasi medik di Banjarmasin masih belum optimal berdasarkan pendapat Anoraga dan Widiyanti (2001) dimana kualitas lingkungan dapat ditentukan dari aspek pertukaran udara, pencahayaan yang cukup, dan kebisingan.

\section{PERMASALAHAN}

Bagaimana rancangan Klinik Utama Rehabilitasi Medik di Banjarmasin yang mengoptimalkan faktor lingkungan dalam perancangan ruang sehingga memberi dampak penyembuh pada fisik dan psikologis pasien?

\section{TINJAUAN PUSTAKA}

\section{A. Tinjauan Klinik Utama}

Klinik merupakan fasilitas kesehatan yang melaksanakan tindakan kesehatan secara mandiri atau perorangan dan secara berkelompok, baik berupa pelayanan medis dasar atau spesialis.

Seseorang yang mengabdikan diri bekerja di sebuah klinik, yang memiliki kecakapan dan kemampuan di bidang kesehatan, serta pernah menempuh pendidikan di bidang kesehatan disebut juga pegawai kesehatan klinik. Berdasarkan jenis pelayanan, klinik dibedakan menjadi dua, yaitu:

- Klinik pratama 
Klinik pratama adalah klinik yang melakukan pelayanan medik dasar, umum, dan khusus.

- Klinik Utama

Klinik utama adalah klinik dimana pelayanan medik yang dilaksanakan bersifat spesialistik atau dasar dan spesialistik.

Perbedaan mendasar antara kedua jenis klinik tersebut yaitu:

Tabel 3 Perbedaan Klinik Pratama dan Klinik Utama

\begin{tabular}{|l|l|}
\hline Klinik Pratama & Klinik Utama \\
\hline $\begin{array}{l}\text { Pelayanan medis hanya } \\
\text { pelayanan medis dasar. }\end{array}$ & $\begin{array}{l}\text { Pelayanan medis termasuk } \\
\text { pelayanan medis dasar dan } \\
\text { spesialis. }\end{array}$ \\
\hline $\begin{array}{l}\text { Kepala klinik merupakan } \\
\text { seorang dokter atau dokter } \\
\text { gigi. }\end{array}$ & $\begin{array}{l}\text { Kepala klinik merupakan } \\
\text { seorang dokter spesialis atau } \\
\text { dokter gigi spesialis. }\end{array}$ \\
\hline $\begin{array}{l}\text { Tindakan rawat inap hanya } \\
\text { boleh pada klinik yang } \\
\text { berbentuk badan usaha. }\end{array}$ & $\begin{array}{l}\text { Boleh melakukan pelayanan } \\
\text { rawat inap. }\end{array}$ \\
\hline $\begin{array}{l}\text { Tenaga medis dua dokter } \\
\text { atau dokter gigi atau lebih. }\end{array}$ & $\begin{array}{l}\text { Tenaga medis merupakan satu } \\
\text { orang spesialis untuk setiap } \\
\text { bentuk pelayanan. }\end{array}$ \\
\hline
\end{tabular}

Sumber: Data Pribadi

\section{B. Tinjauan Rehabilitasi Medik}

\section{Pengertian Rehabilitasi Medik}

Menurut Departemen Kesehatan, rehabilitasi ialah penyembuhan untuk mendapatkan kemandirian individu yang maksimal atau proses menyembuhkan keadaan fisik yang cacat, sosial, kejiwaan dan kekaryaan untuk hidup yang sepantasnya. Berdasarkan hal tersebut pelayanan kesehatan rehabilitasi medik merupakan pelayanan kesehatan yang berfokus terhadap hambatan fisik dan fungsi akibat kondisi cedera,penyakit, atau sakit dengan keterampilan medik, terapi jasmani/ fisik dan rehabilitatif untuk mengembalikan fungsi semula.

\section{Pelayanan Rehabilitasi Medik}

Bentuk pelayanan rehabilitasi medik pada setiap fasilitas kesehatan dibagi berdasarkan tindakan yang dilakukan terhadap pasien,secara umum bentuk pelayanan tersebut terbagi atas :

\section{a. Pelayanan Fisioterapi \\ Pelayanan Fisioterapi ialah ppelayanan kesehatan yang diterapkan}

untuk perorangan atau kelompok untuk pengembangan, pemeliharaan dan penyembuhan gerak dan fungsi tubuh sepanjang hidup dengan tindakan secara manual, terapi gerak, dengan alat elektronik (elektroterapi dan mekanik), serta melatih fungsi dan komunikasi.

\section{b. Pelayanan Terapi Wicara}

Pelayanan Terapi Wicara merupakan bentuk pelayanan kesehatan yang diterapkan kepada perorangan atau kelompok untuk mengembalikan dan mengusahakan pengganti/penyesuaian fungsi komunikasi, menelan, dan bicara dengan cara penyembuhan kembali, menggiatkan dan memfasilitasi (fisik, elektroterapi, dan mekanik).

\section{c. Pelayanan Okupasi Terapi}

Pelayanan Okupasi Terapi adalah bentuk pelayanan kesehatan yang diterapkan untuk perorangan maupun kelompok untuk pengembangan, pemulihan, pemeliharaan fungsi dan atau mengusahakan pengganti/penyesuaian untuk aktifitas sehari-hari, pencapaian dan waktu luang dengan cara keterapian, menggiatkan dan memfasilitasi pasien.

\section{d. Pelayanan Ortotis-Prostetis}

Pelayanan Ortotis-prostetis merupakan salah satu tindakan keteknisian medik yang dilakukan terhadap seseorang untuk membuat, mendesain dan mencocokan alat bantu untuk memelihara dan mengembalikan fungsi, atau pengganti organ gerak.

\section{Tinjauan Konsep Healing Environment}

\section{Pengertian Healing Environment}

Besar pengaruh faktor lingkungan pada proses rehabilitasi individu adalah sebesar $40 \%$, poin lainnya berupa faktor kemedisan berkisar $10 \%$, faktor keturunan berkisar $20 \%$ dan faktor lainnya $30 \%$. Ditinjau dari besarnya pengaruh lingkungan/ alam terhadap proses rehabilitasi tersebut, maka faktor lingkungan perlu dipertimbangkan perannya terhadap rancangan sebuah fasilitas kesehatan. Metode desain yang menempatkan point lingkungan menjadi faktor yang dominan ialah konsep healing environment.

Healing adalah pembangunan keserasian antar personal dan 
ketergantungan antara personal dan lingkungannya. Healing tidak berarti tahapan pengobatan, melainkan upaya pengembalian keseimbangan antara semua bagian tersebut. Dalam keadaan badan yang sehat dapat diartikan bahwa telah terbentuknya keseimbangan, sedangkan dalam keadaan sakit maka tidak ada keseimbangan dalam tubuh.

Menurut Dijkstra (2009) bentuk pengaplikasian konsep healing environment dengan lingkungan kesehatan dapat dilihat dari keadaan akhir pasien, biasanya waktu rawat lebih singkat, besar biaya lebih sedikit, rasa sakit berkurang, tidak ada perasaan stress atau tertekan, menghasilkan keadaan hati yang baik, menumbuhkan kembali semangat, dan meningkatnya kepercayaan individu dengan lingkungannya.

\section{Aspek Pendekatan Pada Healing Environment}

a. Pendekatan Alam

Alam dan elemennya memegang peran penting dalam healing environment. Elemen alam seperti pepohonan, air, langit, batu, bunga dan burung berkontribusi dalam penerapan healing environment pada taman.

\section{b. Pendekatan Indra}

Manusia memiliki indera berupa indera, penglihatan, pendengaran, penciuman, dan peraba. Setiap indera pada manusia ini menjadi faktor penentu tahapan penyembuhan (healing). Pendekatan indera pada ruang dapat dicapai karena adanya persepsi ruang oleh individu pengguna. Respon individu sendiri akan bergantung pada stimulusnya. Pada konsep healing environment ini faktor kualitas ruang seperti pencahayaan, penghawaan, warna, dan lainnya yang berperan sebagai stimulus pada ruang.

\section{c. Pendekatan Psikologi}

Dari dampak psikologis, healing environment menjadikan tahapan pemulihan pasien menjadi singkat, serta mengurangi kemungkinan stress atau tertekan. Tindakan terhadap pasien yang diberikan perlu diperhatikan sesuai keperluan dan poin-poin yang mengarah pada hasil klinis pasien. Bentuk penerapan pendekatan prikologi untuk perawatan pasien, yaitu:

Aspek psikologi diatas dapat dibentuk dari pengorganisasian ruang, penyusunan perabot agar membentuk interaksi yang membangun keakraban antar pengguna dalam ruang.

\section{METODE}

Untuk mendapatkan hasil rancangan yang menampilkan faktor lingkungan sebagai penyembuh, maka metode yang digunakan dalam perancangan Klinik Utama Rehabilitasi Medik ini adalah metode healing environment yang dikemukakan oleh Murphy dimana perancangan dilakukan dengan tiga pendekatan yaitu:

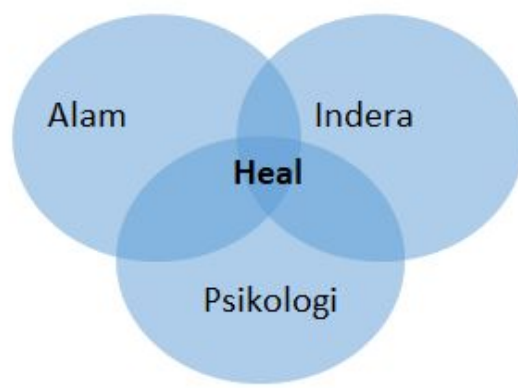

\section{Gambar 1 Pendekatan healing environment} Sumber : www.researchgate.net

Metode healing environment ini dipercaya mempercepat waktu pemulihan kesehatan pasien.

\section{PEMBAHASAN}

\section{A. Konsep Programatik}

Konsep healing environment yang digunakan pada perancangan klinik utama rehabilitasi medik dikemukakan oleh Murphy dimana perancangan dilakukan dengan tiga pendekatan yaitu:

- Alam, pendekatan alam digunakan untuk menghadirkan kenyamanan fisik pada ruang.

- Indera, pendekatan indera untuk menghadirkan citra ruang yang nyaman dan menstimulus kinerja panca indera.

- Psikologi, pendekatan psikologi bertujuan untuk memberikan dukungan emosional pada pasien.

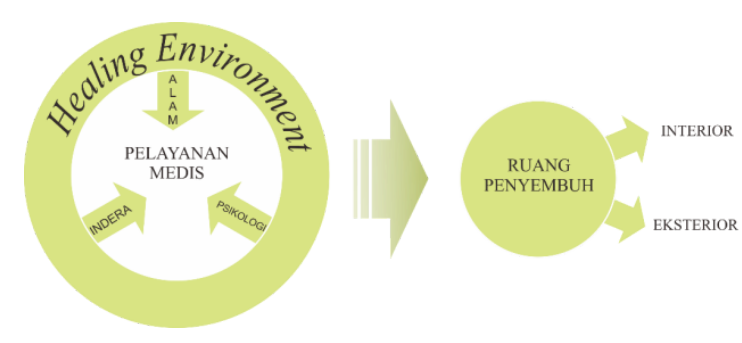


Gambar 2 Konsep programatik Sumber: Analisis pribadi

\section{B. Konsep Eksterior}

\section{Konsep Bentuk}

Bentuk dasar massa pada perancangan Klinik Utama Rehabilitasi Medik ini yaitu bentuk lingkaran dan lengkungan, lingkaran diambil karena bersifat terapeutik (membantu terapi).

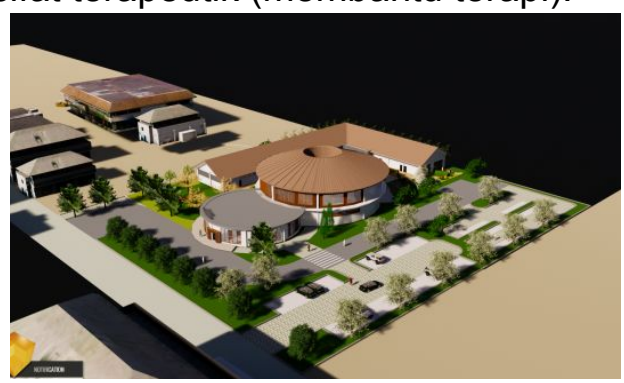

Gambar 3 Perspektif bangunan

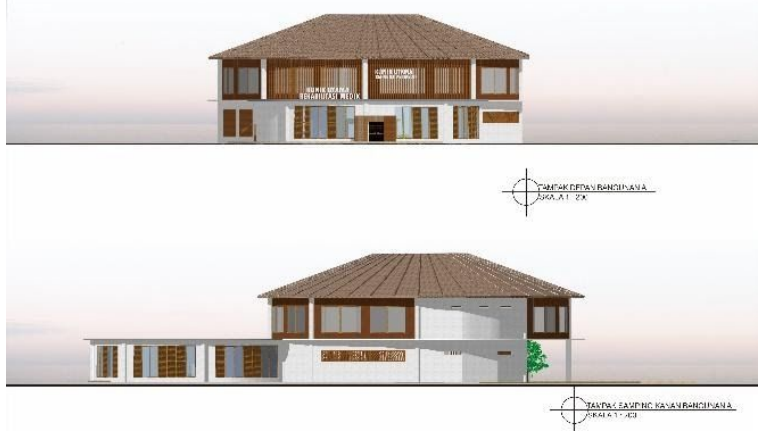

2. Konsep Zona dan Tata Tapak
Gambar 4 Tampak bangunan A
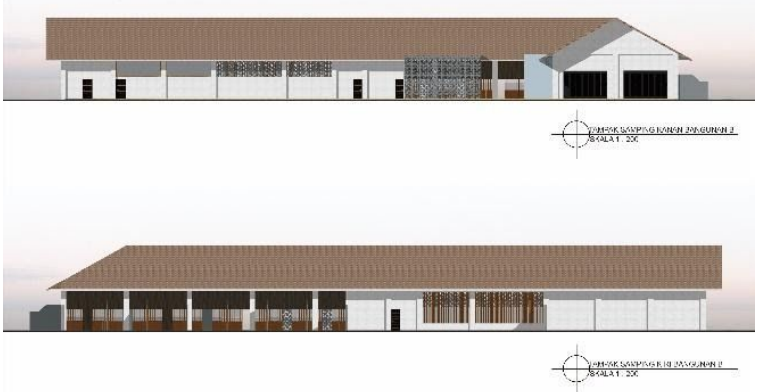

Gambar 5 Tampak bangunan B 


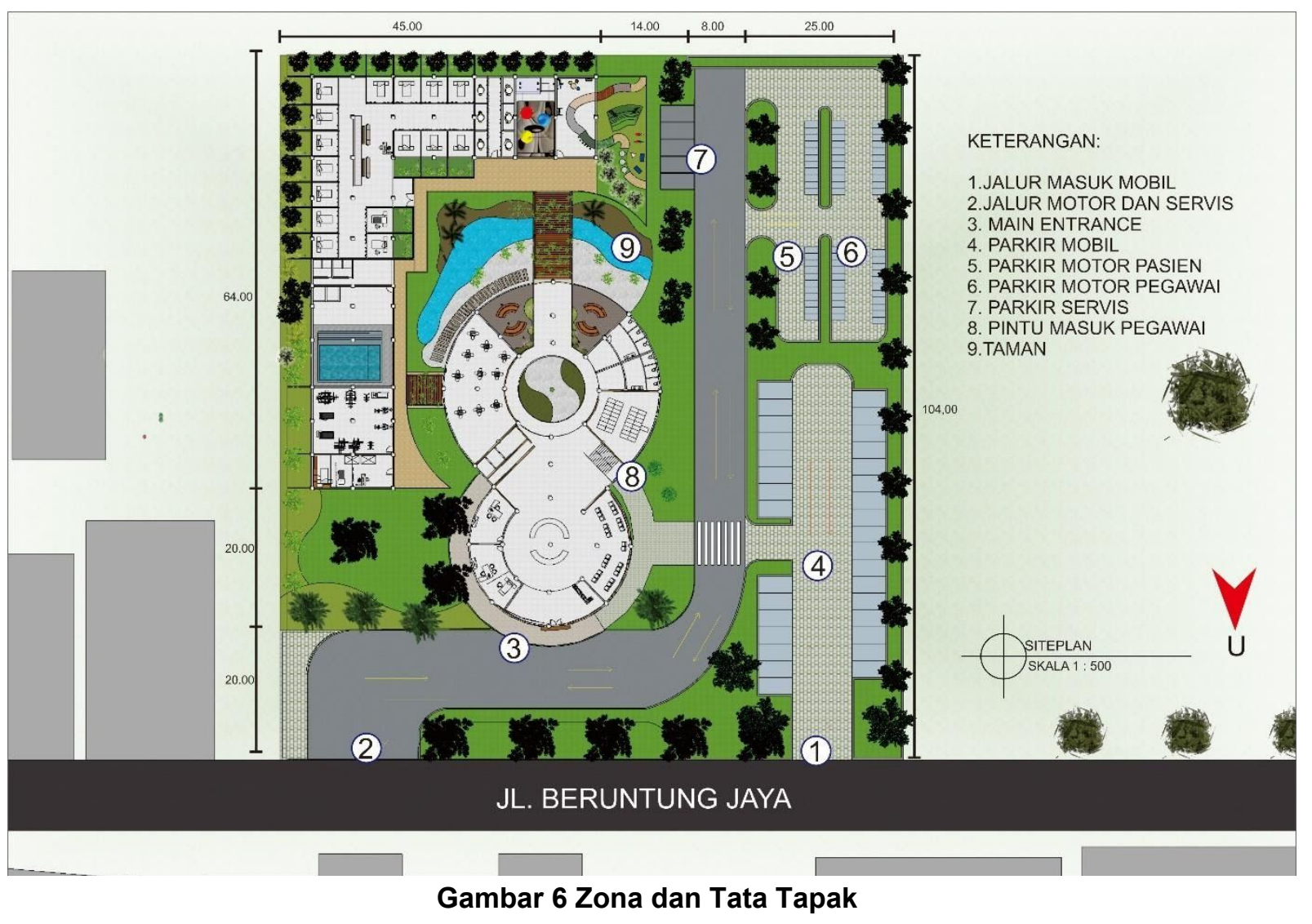

Satu-satunya akses menuju Klinik Utama Rehabilitasi Medik ini yaitu melalui Jalan Beruntung Jaya maka main entrance berada pada jalan tersebut.

\section{Konsep Hardscape dan Softscape}

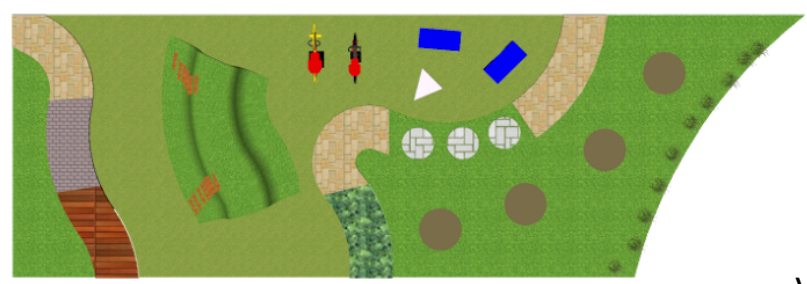

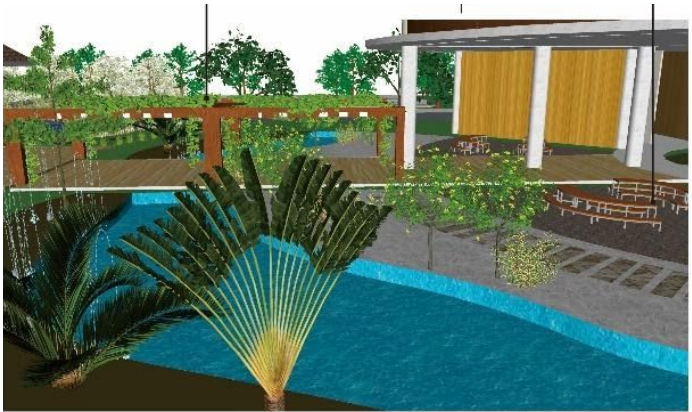

Gambar 8 Sofscape pada tapak

Softscape pada tapak juga merupakan vegetasi yang melengkapi sebuah healing garden, dengan bentuk yang menarik, daun lebar yang menimbulkan suara karena hembusan angin, juga bunga-bunga yang menarik serangga menambah kesan alam pada ruang luar.

\section{Konsep Interior}

\section{Konsep Tampilan Ruang}

Penerapan konsep pada interior tidak terlepas dari tiga aspek yang mendasari healing environment yaitu alam,indera, dan psikologi. Tiga aspek tersebut dihadirkan 
dalam ruang dalam sehingga menghasilkan rancangan dengan desain interior yang memiliki suasana nyaman bagi pengguna ruang.

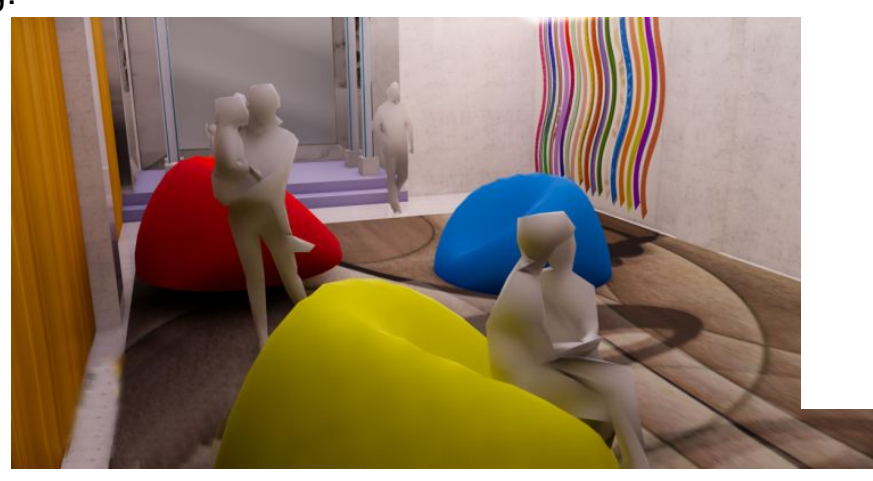

Gambar 9 Penerapan konsep tampilan ruang

Penggunaan warna pada unsur ruang ataupun perabot akan mempengaruhi indera serta psikologis pasien.

\section{Konsep Zona dan Tata Ruang}

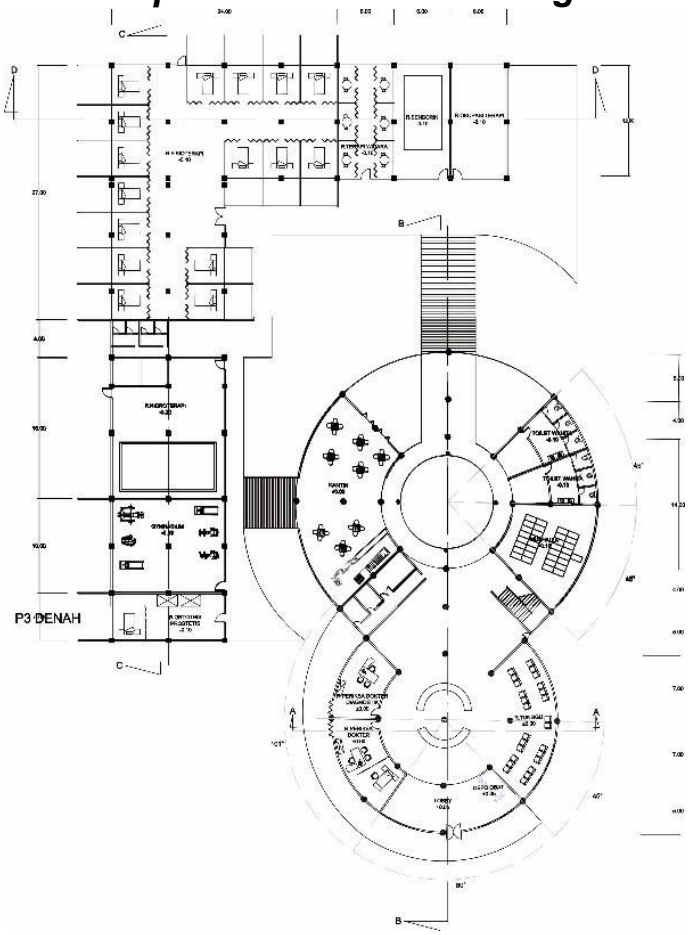

Gambar 10 Denah lantai 1

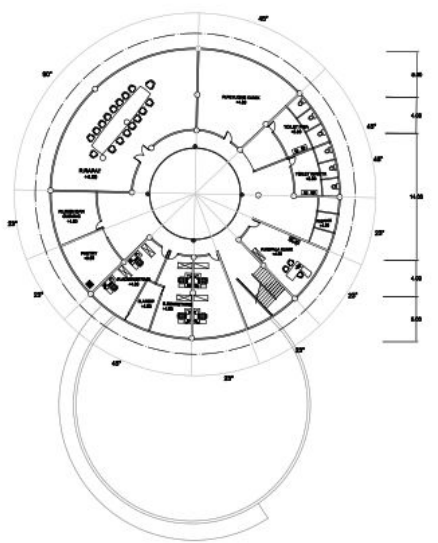

Gambar 11 Denah lantai 2

- Fungsi Lantai 1 lebih difokuskan untuk fungsi utama yaitu pelayanan terapi terhadap pasien serta ruang ruang-ruang sekunder yang menunjang kebutuhan pasien sedangkan lantai 2 difungsikan untuk kebutuhan petugas medik.

- Persyaratan ruang, syarat ruang akan menentukan letak ruang pada bangunan, ruang publik diletakkan di zona depan bangunan, ruang semi publik di zona tengah, dan privat di zona belakang, ruang servis pada zona yang tidak terkena matahari.

- Kebutuhan akan healing environment, ruang yang lebih membutuhkan healing environment diletakkan berdekatan dengan ruang terbuka untuk memaksimalkan faktor alam.

\section{Konsep Hubungan Ruang dengan Alam}

Hubungan ruang dengan alam mempengaruhi proses rehabilitasi pasien. Psikologi pasien lebih positif ketika ruang terapi berhubungan langsung dengan alam. Berikut adalah penerapan hubungan ruang dengan alam pada Klinik Utama Rehabilitasi Medik.

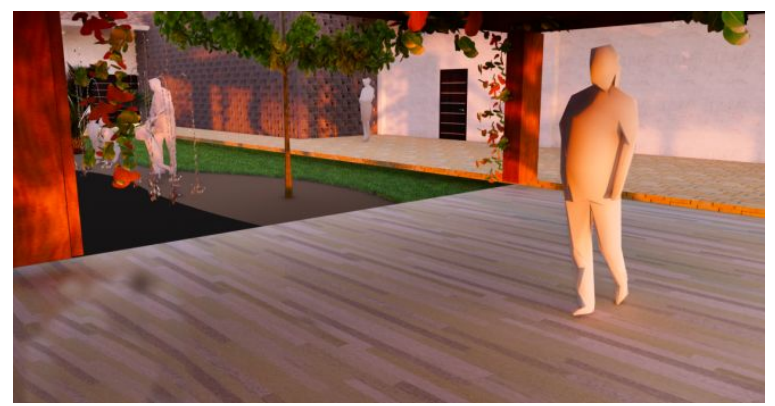

Gambar 12 Ruang luar 
Ruang dalam dikelilingi oleh taman, untuk menuju ruang rehabilitasi pasien akan melewati taman yang membuat perasaan pasien lebih tenang.

\section{Konsep Struktur}

Pondasi yang digunakan pada Klinik Utama Rehabilitasi Medik ini adalah pondasi pacangan galam. Pondasi ini umumnya didirikan di atas tanah yang tanggung kekuatan daya dukungnya rendah.

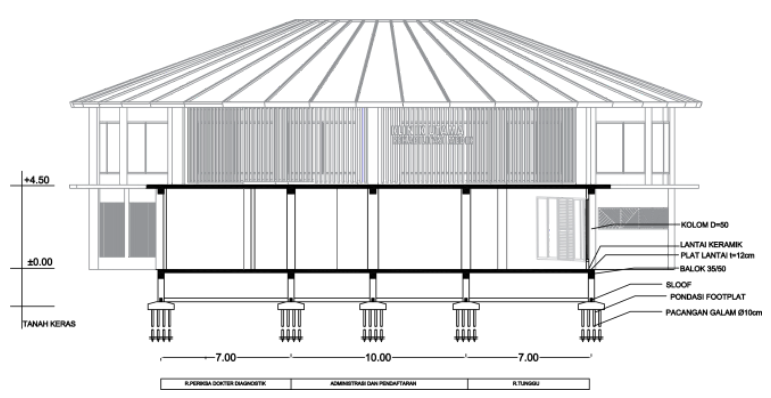

Gambar 13 Potongan bangunan 1 A-A

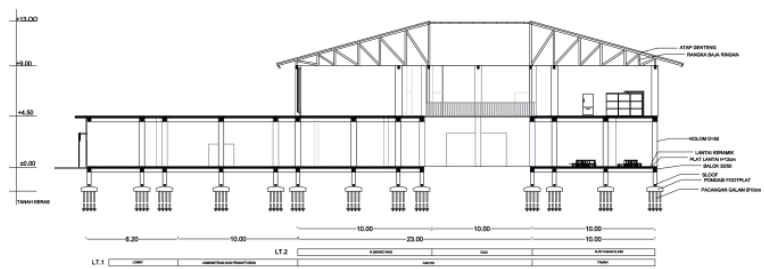

Gambar 14 Potongan bangunan 1 B-B

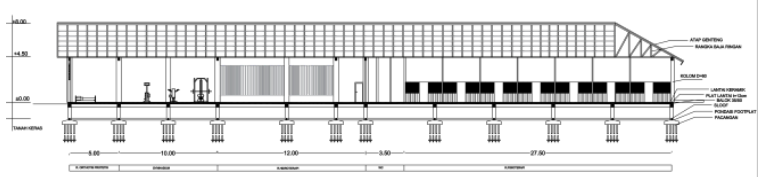

Gambar 15 Potongan bangunan 2 A-A

\section{E. Konsep Utilitas}

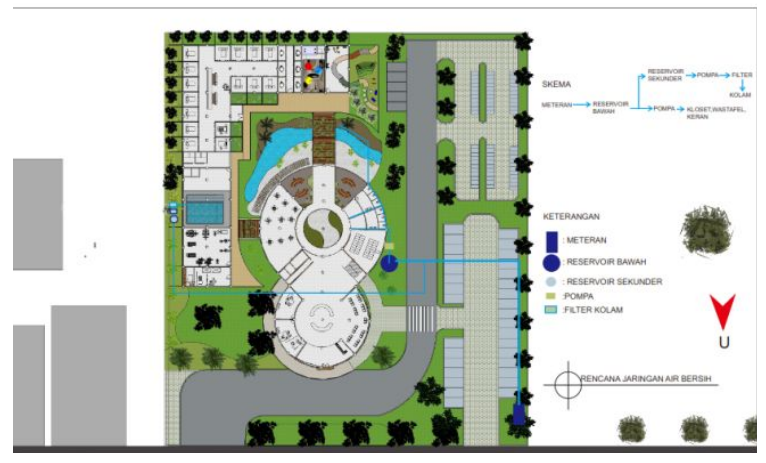

Gambar 16 Utilitas air bersih
Bangunan Klinik Utama Rehabilitasi Medik ini direncanakan berlantai dua. Maka sistem air bersih yang digunakan adalah sistem down feed.

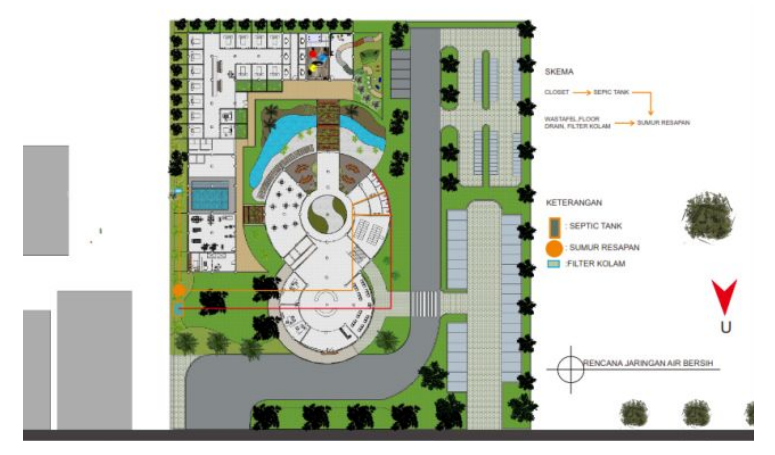

Gambar 17 Utilitas air kotor

Sistem instalasi air kotor dengan cara membuang air kotor dari kloset ataupun urinoir. Air kotor dari bangunan ini dialirkan menuju septictank, selain itu dapat diolah dalam bioseptictank atau instalasi IPAL, kemudian akhirnya dialirkan menuju riol kota.

\section{KESIMPULAN}

Lokasi pembangunan klinik terletak di Jalan Beruntung KM.7 yang memiliki luasan $3600 \mathrm{~m}^{2}$, jarak GSB sebesar $7 \mathrm{~m}$ dari as jalan. Pada luasan site tersebut area Klinik Utama Rehabilitasi Medik yang terbangun sebesar $2300 \mathrm{~m}^{2}$,terdiri atas dua lantai, dan selain area terbangun site yang ada digunakan untuk area hijau dan area parkir.

Konsep healing environment memiliki tiga aspek (alam, indera, dan psikologi). Penerapan aspek konsep healing environment terhadap bangunan yaitu:

- Alam: Perancangan lansekap baik softscape maupun landscape.

- Indera: Pemilihan warna bangunan, pencahayaan, pola pada material, pemilihan material bertekstur, dan hubungan ruang dengan alam untuk menstimulus indera penciuman dan pendengaran.

- Psikologi: Organisasi ruang dan tata perabot.

Struktur yang digunakan yaitu menggunakan pondasi untuk tanah rawa berupa pondasi pacangan galam.

\section{DAFTAR PUSTAKA}

Anoraga, Panji (2001). Psikologi Kerja. Jakarta: Rineka Cipta. 
Dijkstra (2009). Understanding Healing Environments: Effects of Physical Environmental Stimuli on Patients' Health And Well-Being. Enschede: University of Twente.

Fitriyanti,Siti (2014). Arsitektur Interior Rumah Sakit Berdasarkan Evidence-based Design yang Mendukung Healing Environment. Jakarta: Universitas Indonesia

Jones (2003). Health and Human Behaviour. South Melbourne: Oxford University

Pebriano, V, Lidayana, V,Alhamdani, M., (2013). Konsep dan Aplikasi Healing Environment dalam Fasilitas Rumah Sakit. Desember 2013, 3.

Peraturan Menteri Kesehatan RI No 9. (2014). Klinik 